\title{
PROFESIONALISME GURU PAI DAN KEPEMIMPINAN KEPALA SEKOLAH
}

\author{
Oleh : \\ Abdul Halim Mukhtar ${ }^{*}$
}

\section{Abstrak:}

Profesionalisme guru menjadi tuntutan yang harus dipenuhi oleh seorang guru, tidak terkecuali bagi guru PAI. Maka dari sini banyak pihak yang melakukan berbagai upaya untuk meningkatkan profesinalisme guru. Namun perlu dicermati ada bebera faktor yang menentukan profesionalisme guru di antaranya adalah kepemimpinan kepala sekolah dan iklim kerja. Berdasarkan hal itu dilakukan penelitian untuk mengetahui seberapa besar kontribusi kepemimpinan kepala sekolah dan iklim kerja terhadap profesionalisme. Didapat kepemimpinan kepala sekolah tidak berkontribusi secara langsung terhadap profesionalisme guru PAI, namun iklim kerja memiliki kontribusi. Jika kedua variabel itu dianalisis secara bersama-sama maka keduanya memiliki kontribusi terhadap profesionalisme guru PAI.

Kata Kunci, Kepemimpinan, Kerja, Profesionalisme

\section{Pendahuluan}

Profesinalisme guru menjadi tuntutan bagai semua guru tanpa melihat latar belakang pendidikan, keilmuan, budaya, sosial maupun idiologi. Dalam peraturan pemerintah bahwa guru minimal memiliki empat kompetensi sebagai guru profesional. ${ }^{1}$ Seiring dengan itu, guru Pendidikan Agama Islam

* IAI Tribakti Kediri.

1 Penjelasan Peraturan Pemerintah No 19 Tahun 2005 tentang Standar Nasional Pendidikan, yaitu: (1) Kompetensi pedagogik yaitu merupakan kemampuan dalam pengelolaan peserta didik yang meliputi: (a) pemahaman wawasan atau landasan kependidikan; (b) pemahaman terhadap peserta didik; (c)pengembangan kurikulum/ silabus; (d) perancangan pembelajaran; (e) pelaksanaan pembelajaran yang mendidik dan dialogis; (f) 
dituntut pula memiliki profesinalisme yang sama dengan guru lain. Maka, hal mendasar adalah bagaimana mewujudkan guru yang profesional?.

Perlu menganalisis faktor-faktor strategis yang mempengaruhi profesional guru. Di antara faktor tersebut adalah kepemimpina kepala sekolah dan iklim kerja merupakan sebagian dari sejumlah faktor yang dapat mempengaruhi kinerja guru. Peran kepala sekolah di dalam merencanakan, pengorganisasi, pelaksana, komunikasi, motivasi, pengarahan, pengendalian dan pengawasan.

Kepala sekolah merupakan salah satu komponen pendidikan yang paling berperan dalam meningkatkan kualitas pendidikan. Untuk itu kepala sekolah harus mengetahui tugastugas yang harus ia laksankan. Adapun tugas-tugas dari kepala sekolah seperti yang dikemukakan Wahjosumidjo adalah: (1) kepala sekolah bertanggungjawab atas segala tindakannya, (2) mampu menghadapi berbagai persoalan, (3) kepala sekolah harus berfikir secara analitik dan konsepsional, (4) Kepala sekolah adalah seorang mediator atau juru penengah, (5) Kepala sekolah adalah seorang politisi. Kepala sekolah harus dapat membangun hubungan kerja sama melalui pendekatan persuasi

evaluasi hasil belajar; dan (g) pengembangan peserta didik untuk mengaktualisasikan berbagai potensi yang dimilikinya. (2) Kompetensi kepribadian yaitu merupakan kemampuan kepribadian yang: (a) mantap; (b) stabil; (c) dewasa; (d) arif dan bijaksana; (e) berwibawa; (f) berakhlak mulia; (g) menjadi teladan bagi peserta didik dan masyarakat; (h) mengevaluasi kinerja sendiri; dan (i) mengembangkan diri secara berkelanjutan. (3) Kompetensi sosial yaitu merupakan kemampuan pendidik sebagai bagian dari masyarakat untuk : (a) berkomunikasi lisan dan tulisan; (b) menggunakan teknologi komunikasi dan informasi secara fungsional; (c) bergaul secara efektif dengan peserta didik, sesama pendidik, tenaga kependidikan, orangtua/wali peserta didik; dan (d) bergaul secara santun dengan masyarakat sekitar. (4) Kompetensi profesional merupakan kemampuan penguasaan materi pembelajaran secara luas dan mendalam yang meliputi: (a) konsep, struktur, dan metoda keilmuan/teknologi/seni yang menaungi/koheren dengan materi ajar; (b) materi ajar yang ada dalam kurikulum sekolah; (c) hubungan konsep antar mata pelajaran terkait; (d) penerapan konsep-konsep keilmuan dalam kehidupan sehari-hari; dan (e) kompetisi secara profesional dalam konteks global dengan tetap melestarikan nilai dan budaya nasional. 
dan kesepakatan (compromise), dan (6) kepala sekolah adalah seorang diplomat. ${ }^{2}$

Iklim kerja yang menggambarkan suasana dan hubungan kerja antara sesama guru, antara guru dengan kepala sekolah dan antara guru dengan tenaga kependidikan lainnya merupakan wujud dari lingkungan kerja yang kondusif. Suasana seperti ini sangat dibutuhkan oleh seorang guru untuk melaksanakan pekerjaannya dengan lebih efektif. Iklim kerja dapat digambarkan melalui sikap saling mendukung (supportive), tingkat persahabatan (coleagial), tingkat keintiman (intimate) serta kerjasama (cooperative). Iklim kerja tersebut berpotensi meningkatkan profesionalisme guru.

Penelitian ini, sebatas pada faktor yang mempengaruhi profesionalisme guru PAI. Penelitian ini mengasumsikan bahwa profesionalisme guru PAI dipengaruhi faktor iklim kerja yang baik, dengan kata lain dari asumsi di atas maka faktor-faktor lain yang turun mempengaruhi profesinalisme guru PAI tidak dikaji, walaupun tidak menutup kemungkinan ada banyak faktor yang mempengaruhi profesionalisme guru seperti; motivasi, tunjangan, masa kerja dan lain sebagainya.

Iklim kerja merupakan suatu kondisi atau keadaan suasana kerja yang berada di instansi dirasa nyaman, tenang, dan bebas dalam melakukan pekerjaan tanpa adanya rasa takut. Iklim kerja yang menyenangkan akan tercipta, apabila hubungan antar manusia berkembang dengan harmonis. Keadaan iklim yang harmonis ini sangat mendukung terhadap prestasi kerja pegawai. Dengan adanya suasana kerja yang nyaman dan tenang tersebut memungkinkan pegawai untuk bekerja lebih baik. ${ }^{3}$ Iklim kerja merupakan salah satu faktor yang cukup berpengaruh terhadap kepuasan kerja seseorang. Pengaruh iklim kerja akan sangat dirasakan oleh para pegawai dan sangat menentukan dalam mencapai tujuan yang diharapkan. ${ }^{4}$

${ }^{2}$ Wahjosumidjo, Kepemimpinan Kepala Sekolah, (Jakarta: PT Raja Grafindo Persada, 2002), h. 83.

${ }^{3}$ Erwin Dwi Candra Crisdianto, Pengaruh iklim dan motivasi kerja terhadap disiplin pegawai di Kantor Dinas Pendidikan Kota Probolinggo

4 Kukuh Sudarmanto Alugoro, Analisis Pengaruh Iklim Kerja Terhadap Kepuasan Kerja Pegawai Di Sekretariat Daerah Kota Semarang. Masters thesis, Program Pascasarjana Universitas Diponegoro. 2002. 
Bertitik tolak dari latar belakang masalah yang peneliti ajukan, maka peneliti mencoba merumuskan beberapa rumusan masalah sebagai berikut: (1) Bagaimana iklim kerja di SMP? Bagaimana profesionalisme guru PAI? (3) Bagaimana kontribusi iklim kerja terhadap profesionalisme guru PAI?

\section{Metode Penelitian}

Rancangan penelitian ini dengan menggunakan penelitian kuantitatif dengan rancangan penelitian korelasi. Teknik pengambilan sampel dalam penelitian ini menggunakan pendekatan purposis sampling, dari jumlah 32 SMP yang dijadikan sampel sebanyak 14 SMP yang terdiri dari 5 SMP bersetatus Negeri, dan 9 SMP Bersetatus swasta. Sedangkan guru PAI yang dijadikan responden dalam penelitian ini sebanyak 22 guru.

Teknik pengambilan data dengan menggunakan angket, dokumentasi dan wawancara. wawancara dilakukan dalam rangka meng-kros cek informasi tambahan dari responden. Teknik pengangketan, pertama, memberikan angket pada responden yang dituju. Peneliti member waktu dan menunggu responden sampai pengangketan selesai dilaksanakan. Kedua, pengisian angket dilakukan dengan memberikan instrument ke responden, hasil diambil dua - tiga hari setelah menerima angket. Analisis penelitian ini dengan menggunkan rumus regresi dan bantuan program SPSS.

\section{Hasil Penelitian}

Didapat rata-rata kepemipinan kepala SMP adalah 128,82. Median (nilai tengahnya) adalah 129. Modus (nilai yang paling banyak muncul) adalah 130. Standar deviasi adalah 2,805 . Renge atau rentang datanya adalah 10 . Nilai terendah 124 dan nilai tertinggi 134. Maka berdasarkan pada rata-rata kepemipinan kepala SMP sangat tinggi. 


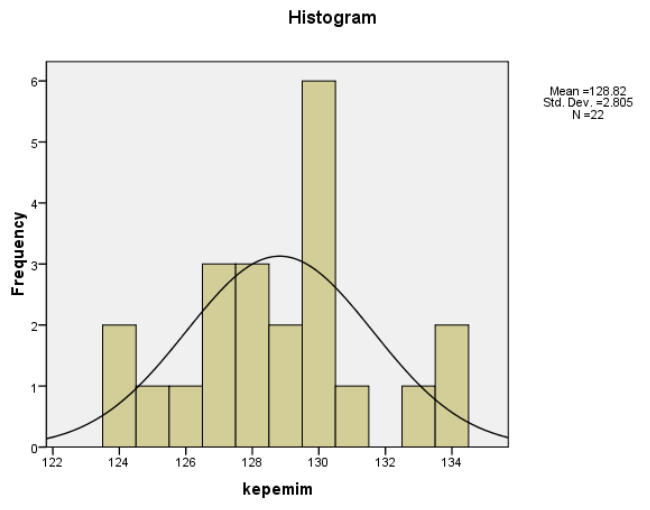

Didapat rata-rata iklim kerja adalah 128,91 Median (nilai tengahnya) adalah 129,00 Modus (nilai yang paling banyak muncul) adalah 128. Standar deviasi adalah 2,975. Renge atau rentang datanya adalah 11 . Nilai terendah 122 dan nilai tertinggi 133. Maka didasarkan pada rata-rata iklim kerja SMP kategori sangat tinggi.

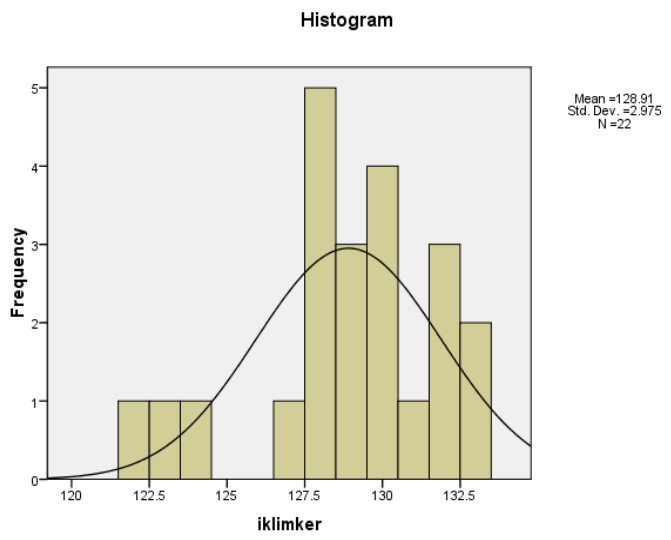

Didapat rata-rata profesionalisme guru adalah 128,55 Median (nilai tengahnya) adalah 129,00 Modus (nilai yang paling banyak muncul) adalah 129. Standar deviasi adalah 3,474 . Renge atau rentang datanya adalah 13 . Nilai terendah 120 dan nilai tertinggi 133. Maka didasarkan pada rata-rata profesionalisme guru PAI SMP kategori sangat tinggi. 


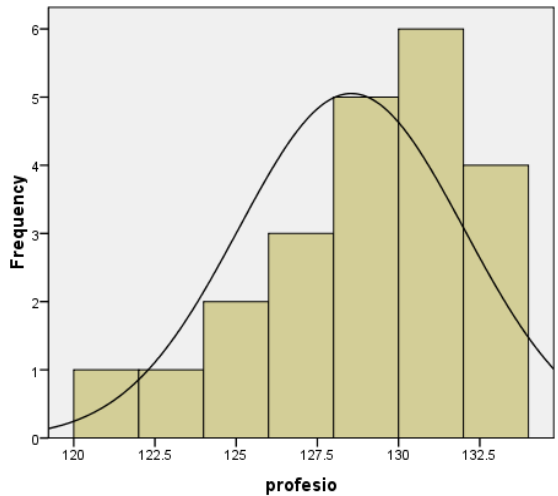

Mean $=128.55$
Std. Dev. $=3.474$
$N=22$

Hipotesis yang diajukan dalam penelitian ini ada empat, yaitu: (1) terdapat kontribusi yang signifikan kepemipinan kepala sekolah terhadap profesionalisme guru PAI; (2) terdapat kontribusi yang signifikan iklim kerja terhadap profesionalisme guru PAI; (3) terdapat kontribusi yang signifikan kepemipinan kepala sekolah terhadap iklim kerja; dan (4) terdapat kontribusi yang signifikan kepemipinan kepala sekolah dan iklim kerja terhadap profesionalisme guru PAI.

Korelasi Kepemipinan Kepala Sekolah, Iklim Kerja dan Profesionalisme Guru Correlations

\begin{tabular}{|ll|r|r|r|}
\hline & & profesio & kepemim & iklimker \\
\hline Pearson & profesio & 1.000 & .514 & .821 \\
Correlation & kepemim & .514 & 1.000 & .671 \\
& iklimker & .821 & .671 & 1.000 \\
\hline Sig. (1-tailed) & profesio & .007 & .000 \\
& kepemim & .007 &. & .000 \\
& iklimker & .000 & .000 & \\
\hline $\mathrm{N}$ & profesio & 22 & 22 & 22 \\
& kepemim & 22 & 22 & 22 \\
& iklimker & 22 & 22 & 22 \\
\hline
\end{tabular}


Pada tabel correlations di atas besarnya korelasi kepemipinan kepala sekolah terhadap profesionalisme guru PAI adalah 0,514. Artinya koefisien korelasi kepemipinan kepala sekolah terhadap profesionalisme guru adalah 'cukup atau sedang'. Didapat signifikansi 0,007 kurang dari 0,05 artinya terdapat korelasi yang signifikan kepemipinan kepala sekolah terhadap profesionalisme guru.

Pada tabel correlations di atas besarnya korelasi iklim kerja terhadap profesionalisme guru adalah 0,821. Artinya koefisien korelasi antara iklim kerja dengan profesionalisme guru Pendidikan Agama Islam adalah 'kuat atau tinggi'. Didapat signifikansi 0,00 kurang dari 0,05 artinya terdapat korelasi yang signifikan antara iklim kerja dengan profesionalisme guru.

Pada tabel correlations di atas besarnya korelasi kepemipinan kepala sekolah terhadap iklim kerja adalah 0,671. Artinya koefisien korelasi kepemipinan kepala sekolah terhadap iklim kerja 'sedang atau cukup'. Didapat signifikansi 0,00 kurang dari 0,05 artinya terdapat korelasi yang signifikan kepemipinan kepala sekolah dengan iklim kerja.

Signifikansi Secara Individual Kepemipinan Kepala dan Iklim Kerja terhadap Profesionalisme Guru PAI Coefficients $^{\mathrm{a}}$

\begin{tabular}{|c|c|c|c|c|c|}
\hline \multirow[b]{2}{*}{ Model } & \multicolumn{2}{|c|}{$\begin{array}{l}\text { Unstandardized } \\
\text { Coefficients }\end{array}$} & \multirow{2}{*}{$\begin{array}{c}\text { Standardized } \\
\text { Coefficients } \\
\text { Beta }\end{array}$} & \multirow[b]{2}{*}{$\mathrm{t}$} & \multirow[b]{2}{*}{ Sig. } \\
\hline & B & $\begin{array}{l}\text { Std. } \\
\text { Error }\end{array}$ & & & \\
\hline 1 (Constant) & 8.929 & 22.202 & & .402 & .692 \\
\hline kepemim & -.083 & .218 & -.067 & -.382 & .707 \\
\hline iklimker & 1.011 & .206 & .866 & 4.914 & .000 \\
\hline 2 (Constant) & 4.997 & 19.243 & & .260 & .798 \\
\hline iklimker & .958 & .149 & .821 & 6.422 & .000 \\
\hline
\end{tabular}

a. Dependent Variable: profesio

Nilai $t$ test $=-0,382$, nilai ini digunakan dalam pengujian koefisien regresi untuk mengetahui apakah variabel independent 
(kepemipinan kepala sekolah) berkontribusi secara signifikan terhadap perubahan nilai variabel dependent (profesionalisme guru PAI). Untuk menguji hipotesis yang diajukan apakah diterima atau ditolak dengan melihat signifikansi. Pada tabel di atas didapat signifikansi sebesar 0,707 , artinya $\mathrm{H}_{\mathrm{a}}$ ditolak dan $\mathrm{H}_{0}$ diterima. Tidak terdapat kontribusi signifikan kepemipinan kepala sekolah terhadap profesionalisme guru. Artinya hipotesis ke 1 ditolak.

Nilai $t$ test $=4,914$, nilai ini digunakan dalam pengujian koefisien regresi untuk mengetahui apakah variabel independent (iklim kerja) berkontribusi secara signifikan terhadap perubahan nilai variabel dependent (profesionalisme guru PAI). Untuk menguji hipotesis yang diajukan apakah diterima atau ditolak dengan melihat signifikansi. Pada tabel di atas didapat signifikansi sebesar 0,000 , artinya $\mathrm{H}_{\mathrm{a}}$ diterima dan $\mathrm{H}_{0}$ ditolak. Terdapat kontribusi signifikan antara iklim kerja terhadap profesionalisme guru. Artinya hipotesis ke 2 diterima.

Signifikansi Secara Individual Kepemimpinan Kepala Sekolah terhadap Iklim Kerja Coefficients $^{\text {a }}$

\begin{tabular}{|c|c|c|c|c|c|}
\hline \multirow[b]{2}{*}{ Model } & \multicolumn{2}{|c|}{$\begin{array}{c}\text { Unstandardized } \\
\text { Coefficients }\end{array}$} & \multirow{2}{*}{$\begin{array}{c}\begin{array}{c}\text { Standardized } \\
\text { Coefficients }\end{array} \\
\text { Beta }\end{array}$} & & \multirow[b]{2}{*}{ Sig. } \\
\hline & B & Std. Error & & & \\
\hline 1 (Constant) & 37.220 & 22.644 & & 1.644 & .116 \\
\hline kepemim & .712 & .176 & .671 & 4.050 & .001 \\
\hline
\end{tabular}

a. Dependent Variable: iklimker

Nilai $t$ test $=4,050$, nilai ini digunakan dalam pengujian koefisien regresi untuk mengetahui apakah variabel independent (iklim kerja) berkontribusi secara signifikan terhadap perubahan nilai variabel independent (kepemipinan kepala sekolah). Untuk menguji hipotesis yang diajukan apakah diterima atau ditolak dengan melihat signifikansi. Pada tabel di atas didapat signifikansi sebesar 0,001, artinya $\mathrm{H}_{\mathrm{a}}$ diterima dan $\mathrm{H}_{0}$ ditolak. Terdapat kontribusi signifikan iklim kerja terhadap kepemipinan kepala sekolah. Artinya hipotesis ke 3 diterima. Adapun ketentuan pengambilan kesimpulan penerimaan dan penolakan 
hipotesis apabila signifikan di bawah atau sama dengan 0,05 maka Ha diterima dan Ho ditolak.

Signifikansi Kontribusi Kepemimpinan Kepala Sekolah dan Iklim Kerja terhadap Profesionalisme Guru PAI

ANOVA $^{c}$

\begin{tabular}{|l|r|r|r|c|c|}
\hline Model & $\begin{array}{r}\text { Sum of } \\
\text { Squares }\end{array}$ & Df & Mean Square & F & Sig. \\
\hline 1 Regression & 171.315 & 2 & 85.657 & 19.814 & $.000^{\mathrm{a}}$ \\
Residual & 82.140 & 19 & 4.323 & & \\
Total & 253.455 & 21 & & & \\
\hline 2Regression & 170.685 & 1 & 170.685 & 41.243 & $.000^{\mathrm{b}}$ \\
Residual & 82.770 & 20 & 4.138 & & \\
Total & 253.455 & 21 & & & \\
\hline
\end{tabular}

a. Predictors: (Constant), iklimker, kepemim

b. Predictors: (Constant), iklimker

c. Dependent Variable: profesio

Tabel anova di atas menunjukan nilai $\mathrm{F}$ hitung sebesar $=$ 19,814 dengan df $1=$ derajat kebebasan pembilang 2 dan df $2=$ derajat kebebasan penyebut 19 dan total df (derajat kebebasannya) 21. Pada kolom signifikansi didapat nilai signifikansi sebesar 0,000 jauh di bawah 0,05 . Artinya benarbenar terdapat kontribusi signifikan kepemipinan kepala sekolah dan iklim kerja terhadap profesionalisme guru Pendidikan Agama Islam. Dengan demikian 'hipotesis ke 4 diterima'. Adapun ketentuan pengambilan kesimpulan penerimaan dan penolakan hipotesis apabila signifikan di bawah atau sama dengan 0,05 maka Ha diterima dan Ho ditolak.

Tabel 5.11

Besaran Kontribusi Kepemimpinan Kepala Sekolah dan Iklim Kerja terhadap Profesionalisme Guru PAI

\section{Model Summary}




\begin{tabular}{|l|r|r|r|r|}
\hline Model & R & R Square & $\begin{array}{c}\text { Adjusted R } \\
\text { Square }\end{array}$ & $\begin{array}{r}\text { Std. Error of } \\
\text { the Estimate }\end{array}$ \\
\hline 1 & $.822^{\mathrm{a}}$ & .676 & .642 & 2.079 \\
2 & $.821^{\mathrm{b}}$ & .673 & .657 & 2.034 \\
\hline
\end{tabular}

a. Predictors: (Constant), iklimker, kepemim

b. Predictors: (Constant), iklimker

Pada tabel Model Summary(b) di didapat 0,822 atas didapat R Square (koefisien determinasi) sebesar 0,676 atau $67,6 \%$. Koefisien diterminasi digunakan untuk mengetahui presentase kontribusi variabel independent (bebas) terhadap perubahan variabel dependent (terikat), sedangkan besarnya kesalahan standar (Se) sebesar 2,079. Variabel independent (bebas) adalah kepemipinan kepala sekolah dan iklim kerja sedangkan variabel dependent (terikat) adalah profesionalisme guru PAI. Besarnya kontribusi kepemipinan kepala sekolah dan iklim kerja terhadap profesionalisme guru hanya 67,6\%, sehingga sisanya 32,4\% disebabkan oleh faktor lain. Dapat pula diartikan bahwa koefisien kontribusi antara kepemipinan kepala sekolah dan iklim kerja terhadap profesionalisme guru sebesar 0,676 dapat diartikan bahwa kontribusi tersebut adalah 'sedang atau cukup'.

\section{Pembahasan}

\section{Kepemimpinan Kepala Sekolah terhadap Profesionalisme Guru PAI}

Berdasarkan pada perhitungan diperoleh koefisien korelasi antara kepemimpinan kepala sekolah dan profesionalisme guru PAI sebesar 0,514 sig. 0,007. Artinya terdapat korelasi antara variable X1 dan Y. Sedangkan besaran kontribusi yang didapat dari $t$ test $=-0,382$ dengan sig. 0,707 dengan demikian kepemipinan kepala sekolah tidak berkontribusi secara langsung terhadap profesionalisme guru PAI.

Berdasarkan temuan tersebut maka dapat ditafsiri bahwa penolakaan ini menurut analisi peneliti disebabkan oleh beberapa faktor: pertama, terjadinya rotasi atau mutasi kepala 
sekolah yang cepat pada beberapa sekolah negeri, sehingga kepala sekolah tidak mampu meyakinkan dalam menggerakan orang lain. Sebagaimana semestinya yang dinyatakan oleh Sadili Samsudin "Kepemimpinan adalah kemampuan meyakinkan dan menggerakkan orang lain agar mau bekerja sama di bawah kepemimpinannya sebagai suatu tim untuk mencapai suatu tujuan tertentu". Maka pada sekolah-sekolah yang mengalami rotasi yang cepat kepemimpinan tidak berjalan secara maksimal.

Kedua, pola manajemen kepemimpinan kepala sekolah yang belum memenuhi standar pengelolaan sekolah. Kepala sekolah harus kompeten dalam menjalankan tugas teknis manajerial yang terdiri atas tiga kategori, yaitu: (1) Impersonal, yaitu kepala sekolah menjalankan fungsi sebagai figur, pemimpin, dan juru runding; (2) Informational, yaitu kepala sekolah menjalankan fungsi sebagai pemantau, penyebar, dan perantara; dan (3) Decisional, yaitu kepala sekolah menjalankan sebagai wiraswastawan, di sturbance-handler, pengalokasi sumber-sumber, dan negoisator. ${ }^{6}$

Ketiga, sistem yang sudah terbangaun secara permanan dibeberapa sekolah. Memungkinkan keberadaan kepala sekolah tidak banyak berpengaruh secara langsung pada profesionalisme guru yang ada. Dikarenakan sistem yang sudah berjalan dengan baik budaya kerja yang terbangun di antara guru pun sudah baik.

5 Sadili Samsudin, Manajemen Sumber Daya Manusia, (Bandung: CV Pustaka Setia, 2006), h. 287. Sementara R. Soekarto Indrafachrudi mengartikan "Kepemimpinan adalah suatu kegiatan dalam membimbing suatu kelompok sedemikian rupa sehingga tercapailah tujuan itu". Soekarto Indarafachrudi, Bagaimana Memimpin Sekolah yang Efektif, (Bogor: Ghalia Indonesia, 2006), h. 2. Kemudian menurut Maman Ukas "Kepemimpinan adalah kemampuan yang dimiliki oleh seseorang untuk dapat mempengaruhi orang lain, agar ia mau berbuat sesuatu yang dapat membantu pencapaian suatu maksud dan tujuan". Maman Ukas, Manajemen, (Bandung: Agini, 2004), h. 268. Sedangkan George R. Terry dalam Miftah Thoha mengartikan bahwa "Kepemimpinan adalah aktivitas untuk mempengaruhi orang-orang supaya diarahkan mencapai tujuan organisasi". Maman Ukas, Manajemen, (Bandung: Agini, 2004), h. 268.

${ }^{6}$ Sudarwan Danim, Inovasi Pendidikan, Dalan Upaya Peningkatan Profesionalisme Tenaga Kependidikan, (Bandung : Pustaka Setia, 2002), h. 137. 
Keempat, pola manajemen kolektif yang terbentuk pada beberapa sekolah swasta. Mendorong budaya kerja yang relative tinggi dalam pencapaian standar minimum yang telah ditetapkan bersama-sama. Dimana keberadaan figur kepala sekolah tidak begitu menentukan dalam keberlangsungan sebuah lembaga. Peningkatan profesionalisme tenaga kependidikan harus dimulai dengan sikap demokratis. Oleh karena itu, dalam membina disiplin para tenaga kependidikan kepala sekolah harus berpedoman pada filar demokratis, yakni dari, oleh dan untuk tenaga kependidikan, sedangkan kepala sekolah tut wuri handayani. ${ }^{7}$

\section{Iklim Kerja terhadap Profesionalisme Guru PAI}

Berdasarkan pada perhitungan diperoleh koefisien korelasi antara iklim kerja dan profesionalisme guru PAI sebesar 0,821 sig. 0,00. Artinya terdapat korelasi antara variable $\mathrm{X} 2$ dan Y. Sedangkan besaran kontribusi yang didapat dari $t$ test $=4,914$ dengan sig. 0,000 dengan demikian iklim kerja berkontribusi signifikan terhadap profesionalisme guru PAI.

Iklim kerja merupakan salah satu faktor yang cukup berpengaruh terhadap kepuasan kerja seseorang. Pengaruh iklim kerja akan sangat dirasakan oleh para pegawai dan sangat menentukan dalam mencapai tujuan yang diharapkan. ${ }^{8}$

Pertama yang harus diperhatikan untuk membangun iklim kerja yang baik adalah bagaimana pemimpin mampu membangun kepercayaan dan ikatan kredibilitas yang baik antara pemimpin dengan bawahan, juga antarsesama bawahan. Kedua, dalam proses pengambilan keputusan, pemimpin harus mampu mengakomodir kepentingan dan kebutuhan dari bawahan. Ketiga, yang menjadi aspek penting dalam membangun iklim kerja yang baik adalah kejujuran dan transparansi pada semua informasi yang diberikan kepada seluruh anggota organisasi. Keempat, iklim organisasi dan lingkungan kerja yang baik mensyaratkan adanya komunikasi

${ }^{7}$ Wahjosumijo, Kepemimpinan Keplas Sekolah, h. 110.

8 Kukuh Sudarmanto Alugoro, Analisis Pengaruh Iklim Kerja Terhadap Kepuasan Kerja Pegawai Di Sekretariat Daerah Kota Semarang. Masters thesis, Program Pascasarjana Universitas Diponegoro. 2002. 
yang terbuka dan berjalan lancar. Komunikasi menjadi salah satu hal prinsip penting dan kunci kesuksesan organisasi. Kelima, untuk bisa membangun iklim kerja yang baik adalah adanya otonomi, serta delegasi wewenang yang memadai bagi bawahan untuk mengambil keputusan. ${ }^{9}$

\section{Kontribusi Kepemimpinan Kepala Sekolah dengan Iklim Kerja}

Berdasarkan pada perhitungan diperoleh koefisien korelasi antara kepemimpinan kepala sekolah dengan iklim kerja sebesar 0,671 sig. 0,00. Artinya terdapat korelasi antara variable $\mathrm{X} 1$ dan X2. Sedangkan besaran kontribusi yang didapat dari $t$ test $=$ 4,050 dengan sig. 0,001 dengan demikian kepemimpinan kepala sekolah berkontribusi signifikan terhadap iklim kerja.

Iklim kerja yang menggambarkan suasana dan hubungan kerja antara sesama guru, antara guru dengan kepala sekolah dan antara guru dengan tenaga kependidikan lainnya merupakan wujud dari lingkungan kerja yang kondusif. Suasana seperti ini sangat dibutuhkan oleh seorang guru untuk melaksanakan pekerjaannya dengan lebih efektif.

Ada beberapa prinsip dalam membangun iklim kerja baik yang dapat dilakukan oleh kepala sekolah: (1) Para tenaga kependidikan akan bekerja lebih giat apabila kegiatan yang dilakukannya menarik, dan menyenangkan. (2) Tujuan kegiatan perlu disusun dengan jelas dan diinformasikan kepada para tenaga kependidikan sehingga mereka mengetahui tujuan dan bekerja. Para tenaga kependidikan juga dapat dilibatkan dalam penyusunan tujuan tersebut. (3) Para tenaga kependidikan harus selalu diberitahu tentang harus dari setiap pekerjaannya. (4) Pemberian hadiah lebih baik daripada hukuman, namun sewaktu-waktu hukuman juga diperlukan. (5) Usahakan untuk memenuhi kebutuhan tenaga kependidikan dengan jalan memperhatikan kondisi fisiknya, memberikan rasa aman, menunjukkan bahwa kepala sekolah memperhatikan mereka, mengatur pengalaman sedemikian rupa sehingga setiap pegawai pernah memperoleh kepuasan dan penghargaan. ${ }^{10}$

\footnotetext{
Akbar Zainudin , Bangunan Iklim Kerja Kondusif, http://majalahqalam.com, diakses pada tanggal 26 Oktober 2011

${ }^{10}$ Wahjosumijo, Kepemimpinan Keplas Sekolah, h. 110.
} 


\section{Kontribusi Kepemimpinan Kepala Sekolah dan Iklim Kerja Terhadap Profesionalisme Guru PAI}

Berdasarkan pada perhitungan diperoleh koefisien korelasi antara kepemimpinan kepala sekolah dan iklim kerja dengan profesionalisme guru PAI sebesar 0,822. Artinya terdapat korelasi antara variable $\mathrm{X} 1$ dan $\mathrm{X} 2$ dengan $\mathrm{Y}$. Sedangkan besaran kontribusi yang didapat dari $\mathrm{F}$ hitung sebesar $=19,814$ dengan sig. 0,000 dengan demikian kepemimpinan kepala sekolah dan iklim kerja berkontribusi signifikan terhadap profesionalisme guru.

Kualitas Pendidikan Agama Islam memiliki ketergantungan pada banyak faktor misalnya guru, kurikulum, sarana prasarana, biaya, sistem pengelolaan, iklim kerja dan siswa sendiri. Di antara sekian banyak faktor, guru dinilai memiliki peran kunci dalam pencapaian kualitas Pendidikan Agama Islam. Hampir semua usaha reformasi pendidikan seperti pembaharuan kurikulum dan penerapan metode pembelajaran baru akhirnya tergantung pada guru. Tanpa mereka pengusaan materi pelajaran, strategi pembelajaran, memotivasi siswa untuk belajar sungguh-sungguh dalam mencapai prestasi, maka segala upaya yang dilakukan untuk meningkatkan kualitas pendidikan tidak akan mencapai hasil maksimal.

Guru profesional merupakan kunci keberhasilan proses pembelajaran. Semua komponen dalam proses pembelajaran materi, media, sarana, dana pendidikan tidak akan memberikan dukungan yang maksimal tanpa didukung keberadaan guru. ${ }^{12}$

Faktor-faktor strategis yang mempengaruhi profesional guru. Di antara faktor tersebut adalah kepemimpina kepala sekolah dan iklim kerja merupakan sebagian dari sejumlah faktor yang dapat mempengaruhi kinerja guru. Kepemimpinan kepala sekolah sangat dibutuhkan untuk dapat meningkatkan profesional guru dan kualitas hasil belajar siswa di sekolah. Peran kepala sekolah di dalam merencanakan, pengorganisasi,

11 Desi Supriadi, Mengangkat Citra dan Martabat Guru, (Yogyakarta: Adicipta Arya Nusa, 1999), h. 178.

12 Ibrahaim Bafadal, Supervisi Pendidikan: Teori dan Aplikasinya dalam Membina Profesionalisme Guru, (Jakarta: Bumi Aksara, 2003), h. 31. 
pelaksana, komunikasi, motivasi, pengarahan, pengendalian dan pengawasan.

Iklim kerja dapat digambarkan melalui sikap saling mendukung (supportive), tingkat persahabatan (coleagial), tingkat keintiman (intimate) serta kerjasama (cooperative). Iklim kerja tersebut berpotensi meningkatkan profesionalisme guru.

Arifiatun, dengan hasil penelitian "Kinerja profesional kepala sekolah mempunyai hubungan yang signifikan terhadap kinerja profesional guru dibuktikan dengan hasil analisis yang menyatakan nilai signifikansi kinerja profesional kepala sekolah adalah adalah 0,013 atau < dari 0.05."13 Muhammad Arifin, dengan hasil penelitian, "Faktor yang mendukung upaya pengembangan profesionalisme guru, yaitu: (a) adanya kemauan dan semangat untuk berkembang; (b) adanya kesempatan yang diberikan oleh pemerintah; (c) adanya dorongan dan dukungan dari pimpinan serta teman sejawat."14 Maka dari hasil penelitian ini dapat disimpulkan bahwa penelitian ini menguatkan dari hasil penelitian sebelumnya.

\section{Kesimpulan}

Berdasarkan analisis data yang berhasil dikumpulkan serta pengujian hipotesis yang diajukan, dapat ditarik kesimpulan sebagai berikut: (1) Koefisien korelasi antara kepemimpinan kepala sekolah dengan profesionalisme guru PAI sebesar 0,514 sig. 0,007. Artinya terdapat korelasi antara variabel X1 dan Y dengan kategori cukup. Sedangkan besaran kontribusi yang didapat dari $t$ test $=-0,382$ dengan sig. 0,707 dengan demikian kepemipinan kepala sekolah tidak berkontribusi secara langsung terhadap profesionalisme guru PAI. (2) Koefisien korelasi antara iklim kerja dan profesionalisme guru PAI sebesar 0,821 sig. 0,00. Artinya terdapat korelasi antara variabel $\mathrm{X} 2$ dan $\mathrm{Y}$ dengan kategori

13 Arifiatun, Kontribusi Supervisi Pengawas Sekolah, Kinerja Profesional Kepala Sekolah dan Pengembangan Profesionalisme Guru terhadap Kinerja Profesional Guru di SMA Negeri Kabupaten Jember, Tesis (Malang: PPS Uiversitas Negeri Malang, 2008).

${ }^{14}$ Muhammad Arifin, Pengembangan Profesi Guru pada Madrasah Tsanawiyah Negeri Malang I, Tesis (Malang: PPS Uiversitas Negeri Malang, 2009). 
sangat tinggi. Sedangkan besaran kontribusi yang didapat dari $t$ test $=$ 4,914 dengan sig. 0,000 dengan demikian iklim kerja berkontribusi signifikan terhadap profesionalisme guru PAI. (3) Koefisien korelasi antara kepemimpinan kepala sekolah dengan iklim kerja sebesar 0,671 sig. 0,00. Artinya terdapat korelasi antara variable X1 dan X2 dengan kategori cukup. Sedangkan besaran kontribusi yang didapat dari $t$ test $=4,050$ dengan sig. 0,001 dengan demikian kepemimpinan kepala sekolah berkontribusi signifikan terhadap iklim kerja. (4) Koefisien korelasi antara kepemimpinan kepala sekolah dan iklim kerja dengan profesionalisme guru PAI sebesar 0,822. Artinya terdapat korelasi antara variable $\mathrm{X} 1$ dan $\mathrm{X} 2$ dengan $\mathrm{Y}$ dengan kategori sangat tinggi. Sedangkan besaran kontribusi yang didapat dari $\mathrm{F}$ hitung sebesar = 19,814 dengan sig. 0,000 dengan demikian kepemimpinan kepala sekolah dan iklim kerja berkontribusi signifikan terhadap profesionalisme guru.

Saran yang diajukan pada para penelitian lanjutan yang ingin memperdalam dan mempertegas penelitian ini adalah sebagai berikut: (1) Penelitian dapat mencoba dengan sampel yang lebih besar, dengan kontek yang berbeda. (2) Diperlukan kecermatan di dalam melakukan pengumpulan data baik pengangketan maupun dokumentasi, agar data yang didapatkan benar-benar sesuai dengan kondisi sabjek yang diteliti. (3) Disarankan peneliti lanjutan dapat melakukan penelitian dengan variabel penelitian yang lebih banyak. 


\section{DAFTAR PUSTAKA}

Alugoro, Kukuh Sudarmanto, Analisis Pengaruh Iklim Kerja Terhadap Kepuasan Kerja Pegawai Di Sekretariat Daerah Kota Semarang. Masters thesis, Program Pascasarjana Universitas Diponegoro. 2002.

Arifiatun, Kontribusi Supervisi Pengawas Sekolah, Kinerja Profesional Kepala Sekolah dan Pengembangan Profesionalisme Guru terhadap Kinerja Profesional Guru di SMA Negeri Kabupaten Jember, Tesis (Malang: PPS Uiversitas Negeri Malang, 2008).

Arifin, Muhammad, Pengembangan Profesi Guru pada Madrasah Tsanawiyah Negeri Malang I, Tesis (Malang: PPS Uiversitas Negeri Malang, 2009).

Bafadal, Ibrahaim, Supervisi Pendidikan: Teori dan Aplikasinya dalam Membina Profesionalisme Guru, (Jakarta: Bumi Aksara, 2003).

Crisdianto, Erwin Dwi Candra, Pengaruh iklim dan motivasi kerja terhadap disiplin pegawai di Kantor Dinas Pendidikan Kota Probolinggo

Danim, Sudarwan, Inovasi Pendidikan, Dalan Upaya Peningkatan Profesionalisme Tenaga Kependidikan, (Bandung: Pustaka Setia, 2002).

Indarafachrudi, Soekarto, Bagaimana Memimpin Sekolah yang Efektif, (Bogor: Ghalia Indonesia, 2006).

Samsudin, Sadili, Manajemen Sumber Daya Manusia, (Bandung: CV Pustaka Setia, 2006)

Supriadi, Desi, Mengangkat Citra dan Martabat Guru, (Yogyakarta: Adicipta Arya Nusa, 1999).

Ukas, Maman, Manajemen, (Bandung: Agini, 2004)

Wahjosumidjo, Kepemimpinan Kepala Sekolah, (Jakarta: PT Raja Grafindo Persada, 2002). 